\title{
Pojem komunitní vzdělávání prizmatem integrované výzkumné strategie
}

\author{
The concept of community education through the prism \\ of an integrated research strategy \\ Lucie Smékalová
}

\begin{abstract}
Abstrakt: Příspěvek prezentuje teoreticko-metodologické uchopení integrovaného výzkumu konceptu komunitní vzdělávání. Integrovaná výzkumná strategie je zde chápána v kontextu psychologického paradigmatu, který je aplikován na proces poznávání a vytváŕí triádu prožívání, vědění, jednání. Výzkumný plán se orientuje zejména na kombinaci kvalitativních a kvantitativních psychosémantických metod na úrovni sběru dat.
\end{abstract}

Klíčová slova: Koncept komunitní vzdělávání, psychosémantické metody, sémantický diferenciál, teorie sociální reprezentace, integrovaná výzkumná strategie.

\begin{abstract}
The paper presents theoretical and methodological grasp of the integrated research on community education concept. Integrated research strategy is understood in the context of the psychological paradigm, which is applied to the learning process and creates a triad experience, knowledge, action. The research plan is focused mainly on a combination of qualitative and quantitative psychosemantic methods on the data collection level.
\end{abstract}

Keywords: The concept of community education, psychosemantic methods, semantic differential, the theory of social representations, integrated research strategy.

\section{Komunitní vzdělávání jako předmět výzkumné strategie}

Komunitní vzdělávání je vrůzných sociálních souvislostech jevem historicky daným a nabývá stále většího praktického významu. Dochází k jeho začleňování do strategických dokumentů, projektů a programů sociálních organizací. Je postaveno na principech (Murphy \& Novák, 2005, s. 10): (a) celoživotní učení, tj. učební př́ležitosti podle potřeb komunity; (b) aktivní zapojení členů komunity při organizování aktivit a rozhodování o komunitních záležitostech; (c) efektivní využívání zdrojů, tzn. fyzické, finanční i lidské zdroje a spolupráce organizací. Jeho cílové skupiny zaujímají celou oblast antropagogiky, kam patří pedagogika, andragogika a geragogika (Švec, 2010, s. 11). V tomto smyslu nabízí komunitní vzdělávání nikoliv protichůdné, ale komplementární př́istupy, které umožňují sociální, kulturní a mezigenerační dialog.

Jelikož učení probíhá po celý život, je chápáno jako antropologická a společenská konstanta (Beneš, 1997, s. 45). Komunitní vzdělávání je tak součástí celoživotního učení a je determinováno politikou nejen sociální, ale i vzdělávací, což prímo vybízí k variabilitě záměrů pro výzkumné strategie. 


\subsection{Koncept komunitního vzdělávání v ČR a zahraniči}

Koncept komunitního vzdělávání lze ve strategických dokumentech naleznout implicitně, bud' se užívá názvu komunitní, nebo je vyjádřena jeho filosofie. Jedná se o dokumenty: (a) Learning: The treasure within (1996), (b) World declaration on Education for All (1990), (c) Národní program rozvoje vzdělávání v ČR (2001), (d) Strategie celoživotního učení ČR (2007) ad.

Evropské dokumenty chápou komunitní vzdělávání v širokém rozsahu činností a institucí se zaměřením na rozmanité cílové skupiny obyvatelstva místní komunity aniž by pro tyto činnosti používaly termínu komunitní vzdělávání. V českých národních dokumentech je situace právě opačná. Principy komunitního vzdělávání jsou redukovány na počáteční vzdělávání v rámci celoživotního učení a na instituci komunitní školy v rámci kurikulárních vizí a rovněž jako prevence proti sociálně patologickým jevům dětí a mládeže. Komunitní vzdělávání má vzhledem k uvedeným dokumentům v ČR vesměs pedagogický rozměr, v zahraničí více andragogický rozměr.

$\mathrm{Na}$ poli praxe existují komunitně orientované programy v ČR i v zahraniční v antropagogickém rozměru. Například v USA existují programy řešící narůstající sociální problémy dětí a to ve spolupráci s př́slušnými agenturami nebo v rámci vládních a komunitních iniciativ (Dryfoos, 1994). Kniha Community education in the western world (1990) poukazuje na specifické potřeby obyvatel v rámci učení v komunitě. V ČR se komunitní vzdělávání uplatňuje zejména v institucích komunitní škola, komunitní centrum, komunitní knihovna. Komunitní školy se rozvíjí dvojím směrem: (a) zaměřují se na dospělou venkovskou populaci, která je znevýhodněna $\mathrm{v}$ přístupu $\mathrm{k}$ dalšímu vzdělání a zaměstnání; (b) nabízí prríležitosti pro spolupráci školy a veřejnosti prostřednictvím inovace kurikula dle aktuálních potřeb.

\subsection{Záměr výzkumné strategie}

Charakteristika a filantropické záměry komunitního vzdělávání zůstávají na úrovni teoretické i praktické zachovány. Vzhledem k rozmanitosti okruhů problémů, obtížnosti zapojení všech cílových skupin a omezeným možnostem té které instituce může docházet $\mathrm{k}$ absenci aplikace komplexního pojetí komunitního vzdělávání. Otázkou zůstává, zda i při této absenci je koncept komunitního vzdělávání komplexně vnímán. Může se totiž stát, že aplikace pouze některých jeho aspektů může mít za následek jeho zkreslené vnímání. Pojem má totiž svůj význam daný charakteristikou a také má určitý smysl, který je utvářen v rámci mentální a sociální reprezentace účastnící se veřejnosti.

Záměrem výzkumné strategie je provést komparaci teoretických východisek pojmu komunitní vzdělávání $\mathrm{s}$ jeho mentálními a sociálními reprezentacemi u respondentio, kteří jsou součástí jeho realizace. Pro teoretické uchopení pojmu je výhodné vycházet z jeho charakteristiky a také z jeho funkcí. Specifikem komunitního vzdělávání podle našeho názoru s odvoláním na diferenciaci manifestních a latentních funkcí vzdělávání podle Mertona (1973) je, že manifestními funkcemi komunitního vzdělávání jsou de facto latentní funkce vzdělávání jako takového. 


\section{Volba integrované výzkumné strategie}

Sociální výzkum bývá specifikován jako „,proces epistemického jednání v rovině teoretické a empirické s cílem nalézt odpověd' na otázky výzkumu, které vyrůstají ze vztahu mezi lidským jednáním a sociálními strukturami“ (Loučková, 2010, s. 25). V našem př́ípadě jde o reflexi pojmu komunitního vzdělávání na základě jeho praktického uplatnění, tedy na základě sociálního jednání (vzdělávání) v dané sociální struktuře (v komunitě).

Ve shodě s Chráskou (2007, s. 32) zastáváme názor, že kvalitativní i kvantitativní výzkumný př́stup má své přednosti a nedostatky, a že je možné, dokonce výhodné oba prístupy kombinovat. Výzkumný záměr odpovídá několika vhodným variantám výzkumného plánu v rámci tzv. mixed model design (Tashakorri \&Teddlie, 1998).

\subsection{Racionalizace záměru volby integrovaného výzkumu}

Pro účel výzkumu je důležité odhalit, jak je pojem komunitní vzdělávání vnímán. Reflexe postihuje rovinu vědomí a prožívání v souvislosti s praktickou aplikací, tedy jednáním. $\mathrm{Z}$ tohoto důvodu je potřebné použít psychologické paradigma aplikované na proces poznávání, to je tvořeno triádou proživání, vědění, jednání. Uvedené paradigma vystihuje (Loučková, 2010, s. 70) interakční a systemické myšlení, které tvoří osu integrovaného př́stupu a které vyjadřuje, že ,jevy a jejich interakce jsou pojímány v souvislosti (kontextu) jejich výskytu jako souhra (dynamický systém)“.

Integrovaný výzkum nám umožňuje nejprve kvalitativní tvorbu zdrojových dat a jejich analýzu (tj. charakteristiku pojmu), následně kvantitativní zpracování deskriptivní a induktivní statistikou (zobecnění), ale i tvorbu hypotéz. Volba integrovaného výzkumu vlastně poukazuje na využití pozitiv, které přináší pozitivismus a hermeneutika v rámci metodologické problematiky v sociálních vědách, tedy kontinuální propojení toho, co Šmausová (2003, s. 14) výstižně nazývá jako presumptivní model rozumění (hermeneutika) a subsumptivní model vysvětlení (pozitivismus).

Jelikož „fenomény jako lidské činy, slova, texty...abstraktní pojmy nejsou pozitivismu př́stupné“ (Šmausová, 2003, s. 12), je potřeba použít kvalitativní přístup, což nám umožňuje charakterizovat koncept komunitní vzdělávání. Zde jde o kontext kladení výzkumných otázek. Tento hermeneutický kruh, je potřebné použít, protože výzkumník musí svému předmětu již předem rozumět (předrozumět), aby byl schopný si vůbec položit smysluplnou výzkumnou otázku. Uvedené předrozumění se týká znalosti společenského kontextu, ve kterém se zkoumaný jev objevuje. Porozumění se děje na základě jazyka, který je schopný se reflektivně uplatnit sám na sebe, umí se zeptat, co ve mně znamená toto slovo a umí si hned sám odpovědět (Šmausová, 2003, s. 13). Z tohoto důvodu je vhodné použít metodu sociální reprezentace.

V rámci kontextu vědecké analýzy (Šmausová, 2003, s. 16) je vhodné užití pozitivistických zásad (ty mohou být přijaty i hermeneutickými př́stupy), jelikož musí splňovat požadavek na intersubjektivní srozumitelnost použitých metod a dosažených výsledků (viz validita a reliabilita). V našem př́padě máme na mysli metodu sémantického diferenciálu a jeho deskriptivní a induktivní statistické zpracování. Dosažené výsledky pak mohou sloužit pro tvorbu dalších výzkumných otázek (kvalitativních nebo kvantitativních). 


\subsection{Zařazení výzkumu v rámci schématu mixed model design}

Užití integrovaného výzkumu kombinuje kvantitativní i kvalitativní př́stup v rámci teze kompatibility, tedy předpokladu, že oba typy výzkumu je možné použít v jedné studii (Hendl, 2008, s. 273).

Nejprve je potřebné zjistit reflexi pojmu komunitní vzdělávání jeho samotnými účastníky v praxi (tzn. východiskem je formulování kvalitativní výzkumné otázky). Následně použijeme metodu sociální reprezentace pro sběr kvalitativních dat. Zjištěná data poslouží jednak pro kvantitativní analýzu dat prostřednictvím metody sémantický diferenciál a jednak pro tvorbu věcných hypotéz (tzn. pro následnou formulaci kvantitativní výzkumné otázky). Pro zpětnou konfrontaci teoretického pojetí pojmu vůči konkrétním specifikacím pojmu u respondentů můžeme aplikovat kvalitativní, případně kvantitativní př́stup.

Vzhledem k možným variacím uchopení výzkumného plánu, lze aplikovat sekvenční design, design s převažující kvantitativní strategií nebo vnořený design $\mathrm{v}$ rámci kombinace zdrojových dat. Uvedené kombinace výzkumu odpovídají klasifikaci druhů smíšeného výzkumu podle Creswell a Plano Clark (2006).

\section{Výzkumný design na úrovni metod}

Výzkumný design se orientuje na psychosémantické metody a techniky výzkumu, kterými jsou sémantický diferenciál a teorie sociálních reprezentací. Zvolené metody umožní nejprve konkretizovat význam pojmu komunitní vzdělávání kvalitativně a následně jej zpracovat kvantitativně.

\subsection{Reflexe metody sociální reprezentace}

Sociální reprezentace je metoda S. Moscoviciho, která „se zabývá vznikem a předáváním přesvědčení sdílených společenskou skupinou či celou společností. Tato sdílená přesvědčení mají důležitou funkci ve vysvětlování reality a společenských činů“" (Hayes, 1998, s. 148).

Touto metodou získáme od respondentů pojmy, které konstrukt komunitního vzdělávání charakterizují. Tyto pojmy mohou být zpracovány pomocí metody strukturální analýzy volných asociací nebo pomocí metody zakotvené teorie. Výsledky analýzy mohou být použity dvojím způsobem pro metodu sémantického diferenciálu, bud' jako objekty pro posuzování nebo jako samotné posuzovací škály. V prŕípadě posuzovacích škál je však zapotřebí provést faktorovou analýzu škál pro stanovení jednotlivých faktorů v sémantickém prostoru respondentů.

\subsection{Reflexe metody sémantický diferenciál}

Sémantický diferenciál je metoda C. Osgooda, která umožňuje měřit vedlejší (konotativní) individuální, psychologické významy pojmů u jednotlivých osob. Na základě určitého počtu posuzovacích škál tvořených dvojicí adjektiv protikladného významu určují probandi své postoje k vymezeným objektům (pojmům). Výsledky posuzovaného pojmu poukazují na mentální reprezentaci pojmu $\mathrm{v}$ sémantickém prostoru respondenta vzhledem ke třem faktorům, kterými jsou faktor hodnocení, potence a aktivity (Chráska, 2007, s. 221).

Pojem komunitní vzdělávání spolu s pojmy, které ho vystihují, jsou použity jako objekty $\mathrm{k}$ posouzení metodou sémantického diferenciálu. Kvantifikací výsledků prostřednictvím tzv. 
lineární distance D v D-matici zjistíme, jak jsou si posuzované pojmy blízké (jsou si podobné významem) nebo vzdálené (liší se významem).

Výsledky nám umožňují jednak zpětně ověřit validitu pojmů danou metodou sociální reprezentace, jednak definovat konstrukt komunitní vzdělávání u respondentů, př́padně korigovat (redefinovat) vytvořené pojetí vůči jeho teoretickému uchopení.

\section{Literatura}

Beneš, M. (1997). Úvod do andragogiky. Praha: Karolinum.

Community education in the western world. (1990). London: Taylor \& Francis Group.

Creswell, J. W., \& Plano Clark, V. L. (2006). Designing and conducting mixed methods research. Thousand Oaks, CA: Sage.

Delors, J. (1996). Learning: The treasure within. Paris: UNESCO Publishing.

Dryfoos, J. (1994). Full-service schools: A Revolution in health and social services for children, youth, and families. San Francisco: Jossey-Bass Publishers.

Hayes, N. (1998). Základy sociální psychologie. Praha: Portál.

Hendl, J. (2008). Kvalitativni výzkum: základni teorie, metody a aplikace. Praha: Portál.

Chráska, M. (2007). Metody pedagogického výzkumu. Praha: Grada.

Loučková, I. (2010). Integrovaný př́stup v sociálně vědním výzkumu. Praha: SLON.

Merton, R. K. (1973). The sociology of science. Chicago: The University of Chicago.

Murphy, K., \& Novák, T. (2005). Př́ručka profesního rozvoje koordinátora komunitního vzdělávání. Praha: Nová škola, o.p.s.

Národní program rozvoje vzdělávání v ČR: Bílá kniha. (2001). Praha: VÚP v Praze.

Strategie celoživotniho učeni ČR. (2007). Praha: MŠMT.

Šmausová, G. (2003). Vybrané metodologické problémy v sociálních vědách: pozitivismus nebo hermeneutika? In D. Šimek (Ed.), Kurikulum andragogiky (pp. 7-18). Olomouc: VUP.

Švec, Š. (2010). Subkultúra pedagogických a andragogických vied. Pedagogika.sk, 1(1), 7-30.

Tashakkori, A., \& Teddlie, C. (1998). Mixed methodology: Combining qualitative and quantitative approaches. Thousand Oaks: Sage Publications.

World declaration on Education for All. (1990). New York: UNESCO Publishing.

\section{Kontakt}

PhDr. Lucie Smékalová, Ph.D.

Univerzita Palackého v Olomouci

Filosofická fakulta, Katedra sociologie a andragogiky

Tř́da Svobody 26, 77147 Olomouc

e-mail: lucie.smekalova@upol.cz

\section{Bibliografické údaje}

Smékalová, L. (2011). Pojem komunitní vzdělávání prizmatem integrované výzkumné strategie. In T. Janík, P. Knecht, \& S. Šebestová (Eds.), Smíšený design v pedagogickém výzkumu: Sborník přispěvki̊ z 19. výročni konference České asociace pedagogického výzkumu (s. 86-90). Brno: Masarykova univerzita.

Dostupné z: http://www.ped.muni.cz/capv2011/sbornikprispevku/smekalova.pdf

doi: 10.5817/PdF.P210-CAPV-2012-63 